Безуглий В. М.

Національний університет оборони України імені Івана Черняховського, Київ

\title{
Можливі підходи до оцінювання ефективності бойової підготовки військових частин надводних сил Військово-Морських Сил Збройних Сил України
}

Резюме. У статті окреслено невідповідності теорії і практики бойової підготовки військових частин надводних сил Військово-Морських Сил, які потребують удосконалення системи бойової підготовки для забезпечення спільного виконання завдань у складі міжвідомчих угруповань. Запропоновано підходи до оцінювання ефективності системи бойової підготовки з урахуванням впровадження спільної підготовки сил оборони.

Ключові слова: бойова підготовка; спільна підготовка сил оборони; надводні сили ВійськовоМорських Сил Збройних Сил України; морська охорона Державної прикордонної служби України.

Постановка проблеми. Значна увага 3 такі показники і критерії, які найбільш повно боку керівництва держави приділяється захисту інтересів держави у морській операційній зоні та розглядається як одне 3 пріоритетних стратегічних завдань. Виключна відповідальність Військово-Морських Сил (ВМС) у захисті національних інтересів у морській операційній зоні, збільшення їх ролі та значення, а також розширення спектра задач вказує, що в сучасній збройній боротьбі відбувається постійне зростання значення застосування угруповання сил (військ) ВМС у складі міжвідомчих угруповань. Надводні сили ВМС можуть i повинні діяти спільно 3 морською охороною Державної прикордонною службою України (МO ДПС) для вирішення пріоритетних завдань на морі, що так само потребує проведення певних спільних заходів бойової підготовки (БП).

Отже, перед системою бойової підготовки Збройних Сил України (ЗС України) стоїть актуальне наукове та практичне завдання удосконалення системи БП, що забезпечуватиме набуття відповідного рівня готовності військової частини надводних сил ВМС до спільного виконання завдань з МО ДПС.

Аналіз останніх досліджень і публікацій. Питанню підвищення ефективності системи БП було присвячено низку попередніх робіт. Автори цих робіт зробили вагомий внесок у розвиток теорії БП. Існуючий науково-методичний апарат, що запропонований у цих роботах дає змогу оцінити рівень організації та ресурсного забезпечення БП, рівень індивідуальної підготовки військовослужбовців, готовність військової частини надводних сил ВМС до виконання завдань за призначенням. Водночас, існуючі методики не повністю враховують зміни які відбулися в практиці застосування сил (військ) [1].

Проте дослідники виходили 3 тих наукових завдань, які були породжені актуальними проблемами практики свого часу, застосовували відображали процеси, що розглядалися. Водночас зміни, які відбулися у практиці БП військових частин свідчать, що їх не достатньо для проведення цього дослідження.

В Україні такі вчені, як В. Телелим [5], А. Сиротенко [6], В. Хома [7], С. Яким'як [8], С. Онищук [9] наголошують на важливості ретельного дослідження питання спільного застосування і підготовки ЗС України та інших військових формувань (IВФ).

Метою статті $\epsilon$ розкриття необхідності впровадження в систему БП спільної підготовки сил оборони, яка буде спрямована на набуття спроможностей спільного виконання завдань військовими частинами надводних сил ВМС i МО ДПС.

Виклад основного матеріалу. Аналіз змін характеру воєнних конфліктів останніх десятиліть дає змогу стверджувати, що на сьогодні зміст війни полягає вже не в розгромі збройних сил противника, а в тому, щоб нанести максимальні втрати політичній волі, населенню, економіці та інфраструктурі держави-жертви агресії, тим самим підпорядкувати цю державу своїй волі.

Саме воєнний конфлікт сучасності й потребує від України об'єднання зусиль сил оборони і застосування їх у складі міжвідомчих угруповань, що зі свого боку потребує їх спільної підготовки для набуття необхідного рівня взаємодії для спільного вирішення завдань.

Події листопада 2018 року в Керченській протоці, вказують на те, що Російська Федерація для недопущення проходу групи катерів надводних сил ВМС, а надалі їх затримання вдалася до застосування Чорноморського флоту Російської Федерації і берегової охорони Прикордонної служби Федеральної служби безпеки Російської Федерації для спільного вирішення завдань саме на морі. 
Також слід зауважити, що Сполучені Штати Америки (США), також звертають увагу на спільне виконання завдань складовими Сил безпеки, для чого в новій стратегії “Армія 2028 року” США визначили створення у 2020 році бригади сприяння Силам безпеки i відповідне командування, це є одними 3 перших заходів практичної частини перевірки експериментального підрозділу Багатодоменна група. Проте питання організації спільної міжвідомчої підготовки США остаточно не розв'язано [10].

Україна, користуючись невід'ємним правом кожної держави на індивідуальну i колективну оборону в разі збройної агресії, вважає правомірним застосовувати воєнну силу для самооборони відповідно до розроблених планів та концепцій застосування всіх складових сектору безпеки і оборони. Для цього слід мати дієву систему спільних дій сил оборони держави. Міністерству оборони України визначені повноваження щодо координації сил оборони 3 питань підготовки держави до оборони.

Отже незаперечним $є$ спільне виконання завдань із захисту суверенітету і територіальної цілісності держави військовими частинами надводних сил ВМС і морської охорони ДПС за умов відсутності можливостей держави щодо швидкого створення угруповання сил (військ) BMC у блокованих районах моря чи на окремій морській операційній зоні. Наврядчи за таких умов ВМС самостійно вирішать в повному обсязі такі завдання, як попередження та протистояння воєнним загрозам на морі, участь у діях 3 розв'язання воєнного конфлікту держави чи сприяння іншим видам, міністерствам у вирішенні покладених на них завдань.

Аналіз спроможностей військових частин надводних сил ВМС і морської охорони ДПС щодо виконання покладених на них завдань свідчить про те, що існують завдання, успішне виконання яких потребує об'єднання сил i засобів цих складових сил оборони. Саме для ефективного виконання таких завдань виникає необхідність об'єднання кораблів (катерів) надводних сил ВМС та морської охорони ДПС в корабельні групи, які за формою та способами застосування відповідатимуть завданням, що на них покладатимуться, і будуть готові діяти як самостійно, так і у складі угруповань. Зі свого боку спільне виконання завдань у складі таких груп додатково потребує спеціальної БП складових сил оборони, а рівень боєздатності військових частин ВМС має забезпечувати спроможність виконання завдань спільно 3 морською охороною ДПС.

3 урахуванням зазначеного, під об'єднаною корабельною тактичною групою пропонується розуміти тимчасове формування, створене 3 кораблів (катерів) складових сил оборони, для спільного виконання тактичних завдань, i яке здатне діяти як у складі угруповання сил (військ) ВМС, так і самостійно, та виконувати завдання під єдиним командуванням.

Провідні науковці наголошують на важливості ретельного дослідження питання спільного застосування та підготовки 3С України та IBФ щодо захисту суверенітету та територіальної цілісності держави. Зокрема, велике значення мають праці науковців [5-9], які звертають увагу на:

проблеми вирішення завдань територіальної оборони у тісній взаємодії 3 іншими військовими формуваннями держави, важливості завчасної підготовки державних резервів, здатних спільно діяти в єдиній системі різностороннього захисту України;

необхідність всебічного, об'єктивного оцінювання всіх чинників, що впливають на підготовку та застосування військ (сил), інших військових формувань та правоохоронних органів держави, управління ними під час спільних дій, необхідність вирішення низки проблемних питань, а саме: до чого i як їх готувати;

характер спільної підготовки органів управління та підрозділів військових частин ЗС України і ДПС України, важливості спільного планування заходів оперативної та бойової підготовки;

необхідність спільного відпрацювання спроможностей ВМС ЗС України та морської охорони ДПС України для здійснення ефективної взаємодії під час спільного виконання завдань безпосередньо на морі;

недостатньо раціональне використання державою власних наявних сил i засобів для інтегрованого виконання завдань оборони держави 3 морського напрямку та охорони державного кордону на морі;

непідготовленості органів управлінь організовувати планування та здійснювати управління угрупованнями, до якого входять підрозділи інших відомств, у процесі виконання завдань під час спільних дій сил оборони;

низький рівень взаємодії та непідготовленість підрозділів спільно діяти під час виконання завдань у складі угруповання, до якого входять підрозділи інших відомств.

Аналізуючи викладене та враховуючи виключну відповідальність ВМС за виконання завдань захисту та оборони держави в діях саме на морі стало зрозуміло, що система БП повинна мати властивості, які забезпечать готовність військових частин надводних сил ВМС діяти спільно з підрозділами морської охорони ДПС та у складі міжвідомчих угруповань.

Нові вимоги до БП на сучасному етапі розвитку ЗС України, які визначені та закріплені 
в концептуальних керівних документах, направлені на розвиток системи БП, адаптованої до армій країн НАТО, основною метою якої $\epsilon$ спрямування системи БП на набуття підрозділами і військовими частинами спроможностей для виконання завдань за призначенням за стандартами підготовки як самостійно, так і у взаємодії 3 іншими складовими сил оборони [4].

Керівництвом Міністерства оборони України та Генерального штабу (ГШ) ЗС України визначено основні напрями удосконалення системи БП:

оптимізація порядку управління підготовкою ЗС України;

удосконалення форм і методів підготовки, урахування досвіду, отриманого під час участі в ATO та OOC [3];

упровадження у процес стандартів підготовки та нової системи оцінювання;

формування вимоги до управління БП i набуття нею властивості здійснювати планування та організації заходів спільної підготовки сил оборони [4];

досягнення

індивідуальних військовослужбовців; необхідного рівня спроможностей

набуття спроможностей щодо виконання завдань за призначенням, зокрема у взаємодії 3 іншими силами оборони, які нажаль оминають спільну бойову підготовку військових частин надводних сил ВМС і МО ДПСУ;

спрямування зусиль індивідуальної підготовки на набуття відповідного рівня навченості військовослужбовців, що забезпечить успішне виконання завдань під час ведення операції Об’єднаних сил;

трансформація існуючих форм (способів) підготовки військ (сил), пошуку нових нестандартних варіантів бойового навчання, які спроможні максимально реалізувати бойовий потенціал військових частин (підрозділів).

Отже, аналізуючи викладене стає зрозумілим, що насамперед система БП має бути адаптованою до армій країн НАТО, включатиме всі функції менеджменту (управлінської діяльності посадових осіб) та забезпечуватиме набуття спроможностей спільно виконувати завдання силами оборони.

До функції менеджменту належать:

“планування" - полягає у формуванні системи планів підготовки загалом і кожної з іiі структурних елементів зокрема, визначає цілі та способи їх досягнення, відображає напрями та завдання підготовки [11];

“організація” - спрямована на побудову організаційної структури i формування в ній управлінської ієрархії, певної системи відносин між окремими структурними підрозділами, що дає їм змогу ефективно взаємодіяти і виконувати завдання підготовки;

“мотивація" - сукупність спонукальних стимулів суб'єктів підготовки, які визначають активність об'єктів підготовки [12];

“контроль" - полягає в своєчасному виявленні відхилень у підготовці суб'єктів підготовки, внесення необхідних коректив, завдяки чому забезпечується реалізація планів заради досягнення навченості об'єктів підготовки.

За допомогою функцій менеджменту суб'єкти спільної підготовки сил оборони зможуть визначати: напрями, цілі та завдання, засоби та ресурси для їх реалізації, організовуватимуть ефективну взаємодію персоналу, контролюватимуть результати та визначатимуть напрями подальшої діяльності.

Отже, ефективність управлінської діяльності системи БП, як процесу, досягається через реалізацію основних функцій менеджменту. Структурна схема основних функцій менеджменту наведена на рис. 1.

Практика потребує впровадження у повсякденну діяльність військових частин надводних сил ВМС спільної БП сил оборони, яка має бути цілеспрямована на відпрацювання взаємодії складових сил оборони, підвищення рівня навченості особового складу, злагодження штабу і підрозділів, набуття спроможностей до спільного виконання завдань 3 іншими складовими сил оборони, що на сьогодні повністю не реалізовано.

Цілком зрозуміло, що ефективність БП військових частин надводних сил ВМС має визначатися рівнем управління БП суб'єктами підготовки та рівнем навченості об'єктів підготовки, з урахуванням набутих властивостей унаслідок впровадження спільної БП сил оборони. Структурна схемі оцінювання ефективності БП військової частини надводних сил ВМС з урахуванням впровадження спільної підготовки сил оборони наведено на рис. 2.

Отже, викладене потребує вирішення наукового завдання, яке полягає в удосконаленні комплексної методики оцінювання ефективності БП військових частин надводних сил ВМС. У подальших дослідженнях слід розглядати узагальнений показник оцінки ефективності БП військової частини надводних сил ВМС, який відповідатиме меті дослідження, міститиме сукупність складових БП, а також реагуватиме на вплив факторів. Фізичний зміст узагальненого показника повинен вказувати на ступінь досягнення кінцевої мети БП - готовності до виконання завдань за призначенням (забезпечення потрібного рівня боєздатності) зокремаі спільно 3 іншими складовими сил оборони. Методика повинна дати змогу здійснювати об’єктивне оцінювання 
індивідуальної підготовки військовослужбовців, урахуванням впливу заходів спільної підготовки колективної підготовки штабів і підрозділів 3 сил оборони.

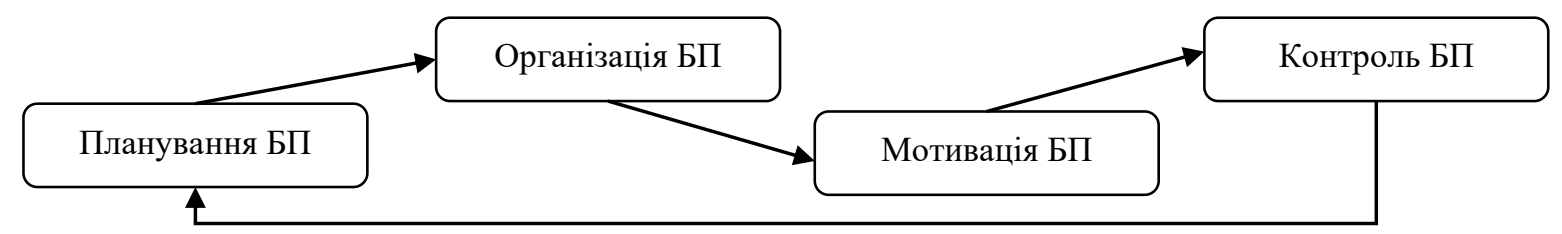

Рис. 1. Структурна схема основних функцій менеджменту

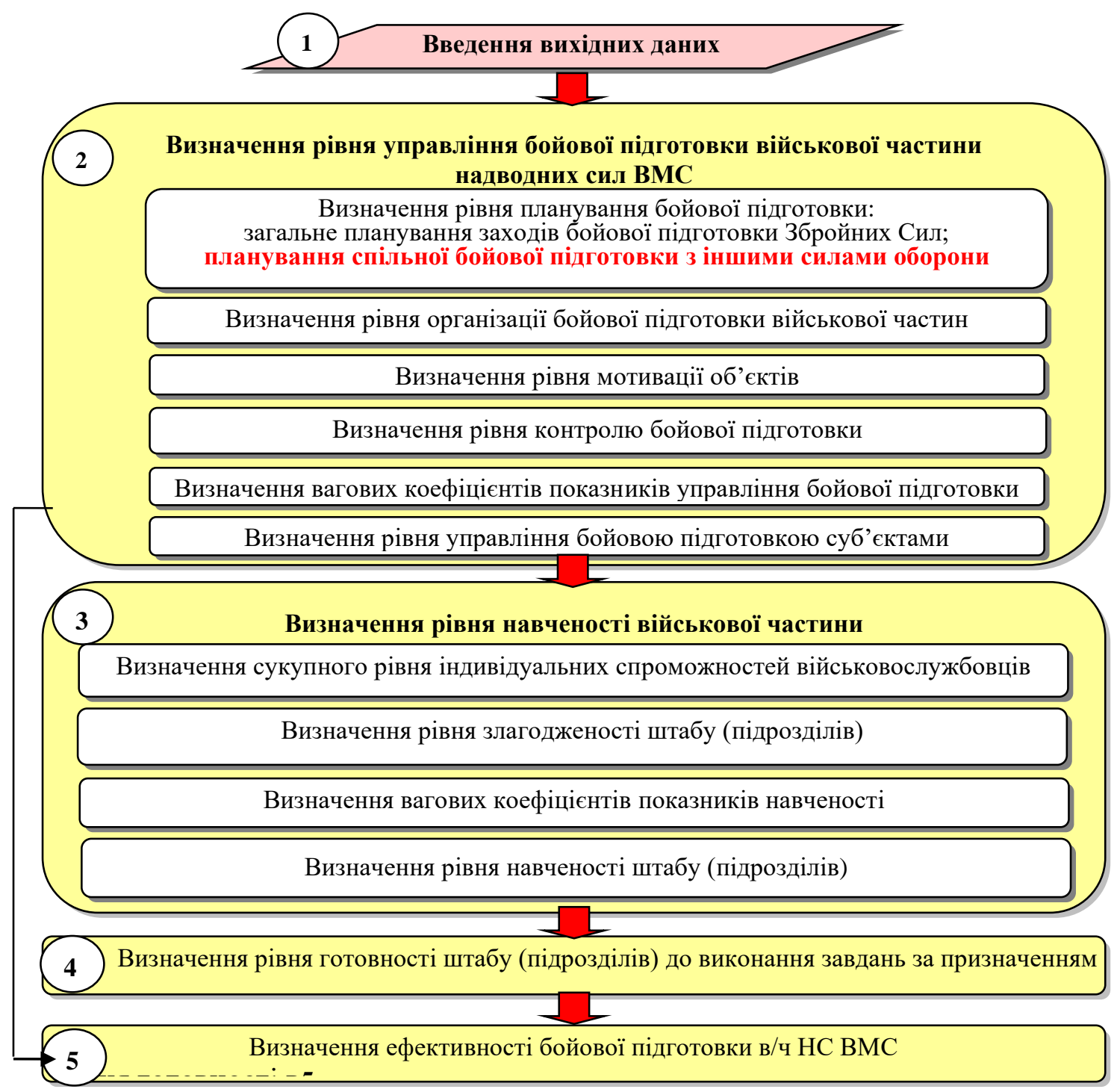

Рис. 2. Структурна схемі оцінювання ефективності БП військової частини надводних сил ВМС з урахуванням впровадження в БП спільної підготовки сил оборони

Підсумовуючи можна зауважити, що комплексна методика оцінювання ефективності БП військових частин надводних сил ВМС забезпечить набуття спроможностей щодо спільного виконання завдань у складі об'єднаних корабельних тактичних групах i забезпечить готовність військових частин надводних сил ВMC до виконання окремих завдань.

Висновки. Наведений підхід оцінювання рівня бойової підготовки військової частини надводних сил ВМС, грунтується на результатах системного аналізу процесу БП військової частини надводних сил ВМС, що враховує основні фактори, які впливають на піi функціонування.

У подальших дослідженнях доцільно приділити увагу розвитку сукупність показників до комплексної методики оцінювання ефективності БП, у якій, на відміну від існуючої, додатково враховуватиметься показник планування спільної підготовки з іншими силами оборони і спрямований на врахування впливу суб'єктів підготовки на навчання об'єктів підготовки, що дасть змогу поліпшити 
навченість особового складу і тим самим вплине на готовність військової частини надводних сил ВМС до виконання завдань за призначенням i набути необхідного рівня підготовки, який забезпечить спільне виконання завдань разом 3 іншими силами оборони.

\section{СПИСОК ВИКОРИСТАНОЇ ЛІТЕРАТУРИ}

1. Георгадзе О. А., Харабара В. І. Часткова методика оцінювання рівня підготовленості танкової бригади у ході відновлення боєздатності. Journal of Scientific Papers "Social development and security”. 2019. Vol. 9, № 4. P. 131-142.

2. Указ Президента України №240/2016 "Про рішення Ради національної безпеки і оборони України від 20 травня 2016 року "Про Стратегічний оборонний бюлетень України” URL: www.president.gov.ua.

3. Концепція підготовки Збройних Сил України : за станом на 22 лют. 2016 р. К. : Міністерство оборони України та ГШ ЗСУ, 2016. 14 с. (Нормативний документ Міністерства оборони України та Генерального штабу Збройних Сил України. Концепція).

4. Єдиний перелік (каталог) спроможностей Міністерства оборони України та Збройних Сил України: за станом на 28 лис. 2017 р. К. : МОУ, 2017. 27 с. (Нормативний документ Міністерства оборони України та Генерального штабу Збройних Сил України).

5. Телелим В. М. Проблеми узгодженого реагування на загрози силами оборони України під час виконання завдань за призначенням. Спільні дї військових формувань $i$ правоохоронних органів держави: проблеми та перспективи: збірник тез доповідей П’ятої Всеукраїнської науково-практичної конференції. 2018. C. 12-13.

6. Сиротенко А. М. Сучасні погляди на форми та способи застосування угруповань військ (сил) Збройних сил
України, інших військових формувань та правоохоронних органів держави під час спільних дій. Спільні діï військових формувань $i$ правоохоронних органів держави: проблеми та перспективи: збірник тез доповідей П'ятої Всеукраїнської науковопрактичної конференції. 2018. С. 8-10.

7. Хома В. В. Вимоги до спільної підготовки i застосування збройних сил та державної прикордонної служби України. Інтегроване управління кордоном. Теорія і практика : збірник тез доповідей Міжнародної науково-практичної конференції. 2013. С. 130.

8. Яким'як С. В. Проблемні питання застосування сил (військ) Військово-Морських Сил Збройних Сил України у складі міжвидових і міжвідомчих угруповань та шляхи їх вирішення. Спільні дї військових формувань $i$ правоохоронних органів держави: проблеми та перспективи: збірник тез доповідей П’ятої Всеукраїнської науково-практичної конференції. 2018. C. $16-17$.

9. Онищук С. В. Проблемні питання спільних дій державної прикордонної служби України 3 іншими військовими формуваннями та правоохоронними органами держави. Спільні діï військових формувань $i$ правоохоронних органів держави: проблеми та перспективи : збірник тез доповідей П'ятої Всеукраїнської науково-практичної конференції. 2018. C. 14-15.

10. Заблоцький В. Забезпечити перемогу у великій війні. Київ, 1923. Ідеологія здорового глузду : матеріали друкованого видання. URL: https://tyzhden.ua/World/228985.

11. Henri Fayol. Administration Industrial et Generale. 1916. Анри Файол. Общее и промышленное управление. Перевод на руський язик: Б.В. Бабина-Кореня. М., 1923. URL: http: gtmarket.ru/laboratory/basis/5783.

12. Варій М. Й. Загальна психологія : підр. для студ. вищ. навч. закл. 3-те вид. К. : Центр учбової літератури, 2009. $1007 \mathrm{c}$.

\section{Безуглый В. М.}

$$
\text { Стаття надійшла до редакційної колегії 11.07.2019 }
$$

\section{Национальный университет обороны Украины имени Ивана Черняховского, Киев}

\section{Возможные подходы к оценке эффективности боевой подготовки военных частей надводных сил Военно-Морских Сил Вооруженных Сил Украины}

Резюме. В статье обозначены несоответствия теории и практики, требующие усовершенствования системы боевой подготовкой, которая будет обеспечивать совместное выполнение задач в составе межведомственных группировок. Обоснованы рекомендации по оценке эффективности системы БП с учетом внедрения в систему БП совместной подготовки сил обороны.

Ключевые слова: боевая подготовка; совместная подготовка сил обороны; надводные силы Военно-Морских Сил Вооруженных Сил Украины; морская охрана Государственной пограничной службы Украины.

\section{Bezuhlyi}

National Defense University of Ukraine named after Ivan Cherniakhovskyi, Kyiv

\section{Possible approaches to evaluation of effectiveness combat training of the surface}

\section{forces of the naval forces of Ukraine}

Resume. The article outlines inconsistencies in theory and practice that require the improvement of a combat training that will ensure joint execution of tasks within interagency groups. Recommendations for evaluating the effectiveness of the combat training system with regard to the introduction of joint training of defense forces into the combat training are substantiated.

Keywords: combat training; joint training of the Defense Forces; surface warfare forces of the Navy of the Armed Forces of Ukraine; coast guard State Border Service of Ukraine. 